\title{
Development Direction Research Of Korean Lifestyle Brands Through Analysis For Global Lifestyle Brands - Focused On The Trend Analysis
}

\author{
Soojin Oh, Hongik University, South Korea \\ Youjin Han, Hongik University, South Korea \\ Keunhee Kwon, Hongik University, South Korea \\ Ken Nah, Hongik University, South Korea
}

\begin{abstract}
As global lifestyle brands are recognized by consumers worldwide, their business are winning a great success. Now that in Korea too, a large-family culture in which members are accustomed to concession and self-sacrifice is changing to a lifestyle of single households, people care a lot about their own properties, privacy, and personalities. As a result, many original cultures reflect that individuals "lifestyles" are emerging. This study suggests development directions for Korean lifestyle brands to grow in line with such social trends and to compete with global lifestyle brands. Based on the survey of Koreans "major lifestyle trends, concepts and products that would represent Koreans" emotions and attract domestic consumers are examined and suggested in this study.
\end{abstract}

Keywords: Lifestyle Brands; Lifestyle Trend; Trend Analysis; Design Management

\section{INTRODUCTION}

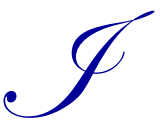
n the second half of 2010, a variety of multi-shops and editing-shops started emerging in pursuit of lifestyle shops. Aiming at consumers of different lifestyles, stores named "lifestyle shops" have increased in number and enhanced the quality in general. Besides, global lifestyle brands have advanced into Korea recently, and their number is increasing rapidly. In response, domestic companies are creating their own brands of Korean lifestyle shops although they have yet to be systematized and established as global lifestyle brands have been.

This study defines the concept of lifestyle brands accurately and seeks the direction of Korean lifestyle brands for their successful development. In addition, the success factors of global lifestyle brands are analyzed to design brands that fit domestic consumers "lifestyles."

First, the theoretical background of lifestyle brands was examined. Currently, as the concept of "lifestyle" is uncertain, the term is defined based on the investigation of related businesses and historical background. The current conditions of lifestyle brands, home and abroad, have also been examined. Second, among the analyzed global lifestyle brands, major brands of high regional sales, expandability of businesses, and accurate concepts were selected and analyzed through marketing mix and SWOT. Third, lifestyle brand trends in Korea were analyzed: first of all, they were examined in macroscopic perspectives of Society, Economy, and Technology; second, they were examined in terms of Industry and Consumer; third, keywords were then extracted by analyzing the two trends. Fourth, based on the analysis results above, advantages of global lifestyle brands and domestic researches were comprehensively investigated to address the direction of future Korean lifestyle brands for their successful development. 


\section{LIFESTYLE BRAND}

\section{Definition}

There is no clear definition of lifestyle brands yet. In the initial stage of this type of business in Korea, the term, lifestyle brands, started to be used, and existing living and fashion brands also tended to expand their boundaries to lifestyle brands. As a brand is launched or developed, its business concept and type may be different depending on the business category. In terms of lifestyle shop business, a lifestyle brand is a business entity that provides total commodities essential in life such as clothing, accessories, furniture, fabrics, household articles, and stationeries and suggests lifestyles that consumers desire. In terms of distribution, it may be called a "Lifestyle Retail Brand." Lifestyle Retail Brand is a focused retail brand, targeted at a specific market segment defined by lifestyle. The basic retail proposition is augmented with a set of added values that have symbolic value and meaning for the lifestyles of a specific consumer group.

Lifestyle brands are suitable to inspire, guide and motivate people, contributing to the definition of their way of life. They bear an ideology, gathering around them a relatively high number of people, thus becoming a recognised social phenomenon. Hence, lifestyle brands show lifestyles and cultures of a group of people including clothing, food, and housing in one general concept. Commodities that express all these items are sold, and ideal lifestyles that consumers seek are suggested.

\section{History and Background}

Including "Marimekko," which is a Finland brand released in 1951, and "MUJI," a Japanese lifestyle brand released in 1980, global lifestyle brands started far earlier than Korean brands. In 1990s, domestic lifestyle shops started to carrying simple and miscellaneous goods in addition to clothing as multi-shops and editing-shops emerged in fashion industry. Large outlets selling household items were the origin of lifestyle brands. In fact, B\&Q, a famous British brand, entered the Korean market although it failed within two years. As some foreign brands failed after advancing into domestic markets, there were no longer similar attempts. In 1999, Kosney, a domestic lifestyle brand, appeared and opened more than 30 shops, which became popular soon, but the number decreased down to 6 and ended up being sold to one fashion company. As MUJI, a Japanese brand, celebrated its 10th anniversary of business in Korea last year, the recognition of lifestyle brands in Korea started to turn rising. In addition, other global lifestyle brands advanced into Korean market and now are competing with domestic lifestyle brands.

\section{Domestic and International Current State}

Since lifestyle brands started abroad, the current condition of global lifestyle brands had to precede the research on existing brands in general. Items were categorized by regions such as USA, EUROPE, and AISA. The concepts, items, prices, and shop distribution of each brand were examined. Additionally, Korean brands were investigated for domestic researches.

\section{USA}

As described in Table 1, the U.S., URBAN OUTFITERS reflects the typical lifestyle so well that it is viewed as representing general American lifestyle. ANTHROPOLOGIE is well known for the theme display with NorthEuropean emotions. These two brands and their identities are recognized worldwide. Recently, CRATE \& BARREL also is attracting interests among consumers. 
Table 1. Information of Lifestyle Brands in USA

\begin{tabular}{|c|c|c|c|c|c|}
\hline BRAND & COMPANY & CONCEPT & ITEM & PRICE & STORE \\
\hline $\begin{array}{c}\text { URBAN } \\
\text { OUTFITERS }\end{array}$ & Philadelphia, PA & $\begin{array}{l}\text { Commercialization of } \\
\text { American free style } \\
\text { that features vintage } \\
\text { and unique youth and } \\
\text { resistance }\end{array}$ & $\begin{array}{l}\text { clothing, shoes, } \\
\text { accessories, beauty, } \\
\text { home \& gifts, vintage } \\
\text { item (LP player, } \\
\text { album, camera) }\end{array}$ & $\begin{array}{l}\text { Fashion: } \\
\$ 16.00 \sim \$ 304.00 \\
\text { Beauty: } \\
\text { \$1.99 } \$ 300.00 \\
\text { Living: } \\
\text { \$19.00 } \sim \$ 749.00\end{array}$ & $\begin{array}{l}\text { More than } 140 \text { shops } \\
\text { in the U.S., Canada, } \\
\text { Europe, etc. }\end{array}$ \\
\hline $\begin{array}{l}\text { ANTHRO- } \\
\text { POLOGIE }\end{array}$ & Philadelphia, PA & $\begin{array}{l}\text { America's natural } \\
\text { brand with North } \\
\text { European emotions }\end{array}$ & $\begin{array}{l}\text { clothing, shoes, } \\
\text { accessories, living \& } \\
\text { furniture }\end{array}$ & $\begin{array}{l}\text { Fashion: } \\
18.00 \sim \$ 500.00 \\
\text { Beauty: } \\
16.00 \sim \$ 898.00 \\
\text { Daily Supplies: } \\
\$ 40.00 \sim \$ 538.00 \\
\text { Living \& Furniture: } \\
\$ 198.00 \sim \$ 5698.00\end{array}$ & $\begin{array}{l}\text { operates over } 175 \\
\text { retail stores } \\
\text { worldwide }\end{array}$ \\
\hline $\begin{array}{c}\text { CRATE } \\
\& \text { BARREL }\end{array}$ & Northbrook, IL & $\begin{array}{l}\text { Simple, modern, } \\
\text { unique, and primary } \\
\text { colored design for } \\
\text { stylish image }\end{array}$ & $\begin{array}{l}\text { furniture, outdoor } \\
\text { living, dining \& } \\
\text { entertaining, kitchen } \\
\& \text { food, decorating \& } \\
\text { accessories, bed \& } \\
\text { bath }\end{array}$ & $\begin{array}{l}\text { Living: } \\
\quad \$ 23.97 \sim \$ 599.00 \\
\text { Home \& Furniture: } \\
\quad \$ 19.00 \sim \$ 2.699 .000 \\
\text { Food: } \\
\quad \$ 0.97 \sim \$ 39.95\end{array}$ & $\begin{array}{l}\text { More than } 170 \text { shops } \\
\text { in North America }\end{array}$ \\
\hline
\end{tabular}

\section{Europe}

Recently, European lifestyles are attracting a number of consumers around the world. Korea is not an exception as Kinfolk Life, one of the recent trends, is the mainstream and consumers prefer practical, simple, but unique items. (Table 2.) Europe owns a number of brands such as COLETTE whose concept is clear and unique. GANT, an American style brand, owns a lot more shops in the U.S., but it actually began in Sweden, and the head office was relocated from the U.S. back to Sweden. Thus, this was classified as a European brand.

Table 2. Information of Lifestyle Brands in EUROPE

\begin{tabular}{|c|c|c|c|c|c|}
\hline BRAND & COMPANY & CONCEPT & ITEM & PRICE & STORE \\
\hline $\begin{array}{l}\text { MARKS \& } \\
\text { SPENCER }\end{array}$ & UK & $\begin{array}{l}\text { Quality, value, } \\
\text { service, innovation, } \\
\text { and reliability }\end{array}$ & $\begin{array}{l}\text { style \& living, } \\
\text { beauty, kids, home \& } \\
\text { garden, food \& wine, } \\
\text { flowers \& gifts }\end{array}$ & $\begin{array}{l}\text { Fashion: } \\
£ 1.99 \sim £ 159.00 \\
\text { Beauty: } \\
4.00 \sim £ 75.00 \\
\text { Household goods: } \\
£ 1.00 \sim £ 2,199.00\end{array}$ & $\begin{array}{l}10 \text { in Korea, } \\
\text { more than } 300 \text { in } \\
\text { the U.K., more } \\
\text { than } 600 \text { shops in } \\
34 \text { countries } \\
\text { around the world }\end{array}$ \\
\hline $\begin{array}{l}\text { CATH- } \\
\text { KIDSTON }\end{array}$ & UK & $\begin{array}{l}\text { Pleasant and modern } \\
\text { vintage concept of } \\
\text { lifestyle brand }\end{array}$ & $\begin{array}{l}\text { clothing, bag, } \\
\text { accessories, kids, } \\
\text { home }\end{array}$ & $\begin{array}{l}\text { Fashion: } \\
£ 4.00 \sim £ 75.00 \\
\text { Accessories: } \\
£ 3.00 \sim £ 50.00 \\
\text { Fabric: } \\
£ 14.00 \sim £ 20.00 \\
\text { Living: } \\
£ 1.50 \sim £ 145.00 \\
\text { Bag: } \\
£ 4.00 \sim £ 125.00\end{array}$ & $\begin{array}{l}130 \text { stores } \\
\text { Worldwide }\end{array}$ \\
\hline PRIMARK & Ireland & $\begin{array}{l}\text { With the motto: } \\
\text { "Good Look Pay } \\
\text { Less" }\end{array}$ & $\begin{array}{l}\text { clothing, shoes, } \\
\text { accessories, cosmetic, } \\
\text { home }\end{array}$ & $\begin{array}{l}\text { Men: fashion } \\
£ 3.00 \sim £ 35.00 \\
\text { Women: fashion } \\
£ 3.00 \sim £ 35.00 \\
\text { Kids: } \\
£ 2.00 \sim £ 15.00 \\
\text { Home: } \\
£ 2.00 \sim £ 20.00\end{array}$ & $\begin{array}{l}125 \text { in the U.K., } \\
34 \text { in Ireland, } 8 \\
\text { in Spain; } 161 \\
\text { fashion stores in } \\
\text { total }\end{array}$ \\
\hline
\end{tabular}




\begin{tabular}{|c|c|c|c|c|c|}
\hline BRAND & COMPANY & CONCEPT & ITEM & PRICE & STORE \\
\hline $\begin{array}{c}10 \text { CORSO } \\
\text { COMO }\end{array}$ & Italy & $\begin{array}{l}\text { unexpected surprises } \\
\text { and small treasures } \\
\text { may be found } \\
\text { through slow } \\
\text { shopping }\end{array}$ & $\begin{array}{l}\text { fashion, life style, } \\
\text { design book, music }\end{array}$ & $\begin{array}{l}\text { Fashion: } \\
€ 45,00 \sim € 940,00 \\
\text { Design: } \\
€ 20,00 \sim € 1,980.00 \\
\text { Living: } \\
€ 3.00 \sim € 185.00 \\
\text { Accessories: } \\
€ 60.00 \sim € 1,400,00\end{array}$ & $\begin{array}{l}\text { Milano_Head } \\
\text { shop, Seoul_- } \\
\text { Lotte Avenue/ } \\
\text { Cheong-dam, } \\
\text { Shanghai, Tokyo }\end{array}$ \\
\hline COLETTE & France & $\begin{array}{l}\text { 'It must be always } \\
\text { new, refreshing, and } \\
\text { surprising. It must } \\
\text { always keep ahead of } \\
\text { others.' }\end{array}$ & $\begin{array}{l}\text { clothing, shoes, } \\
\text { accessories, lingerie, } \\
\text { kids, home, music, } \\
\text { design \& culture }\end{array}$ & $\begin{array}{l}\text { Clothing: } \\
€ 6.00 \sim € 3,600.00 \\
\text { Accessories: } \\
€ 10.00 \sim € 4,300.00 \\
\text { Kids: } \\
€ 4.00 \sim € 585.00 \\
\text { Design \& culture: } \\
€ 5.00 \sim € 2,500\end{array}$ & $\begin{array}{l}\text { Head shop__213 } \\
\text { rue Saint-Honoré } \\
75001 \text { Paris }\end{array}$ \\
\hline IKEA & Sweden & $\begin{array}{l}\text { To be more pleasant } \\
\text { everyday; to be } \\
\text { available for as many } \\
\text { people as possible }\end{array}$ & $\begin{array}{l}\text { furniture, kids, } \\
\text { textiles \& rugs, } \\
\text { interior, kitchen \& } \\
\text { appliance }\end{array}$ & $\begin{array}{l}\text { Bedroom: } \\
\$ 5 \sim \$ 700 \\
\text { Kids room: } \\
\$ 5 \sim \$ 370 \\
\text { Living room: } \\
\$ 5 \sim \$ 800 \\
\text { Kitchen \& appliance: } \\
\$ 3 \sim \$ 1500 \\
\text { Textiles \& rugs: } \\
\$ 5 \sim \$ 300\end{array}$ & $\begin{array}{l}\text { More than } 280 \\
\text { shops in } 38 \\
\text { countries around } \\
\text { the world }\end{array}$ \\
\hline GANT & Sweden & $\begin{array}{l}\text { American style } \\
\text { casual (founded in } \\
1949 \text { in the U.S.) }\end{array}$ & $\begin{array}{l}\text { clothing, shoes, } \\
\text { accessories, beauty, } \\
\text { home }\end{array}$ & $\begin{array}{l}\text { Men: clothing } \\
\text { \$18.00 \$500.00 } \\
\text { Accessories: } \\
\text { \$10.00 \$550.00 } \\
\text { Women: clothing } \\
\text { \$45.00 \$495.00 } \\
\text { Accessories: } \\
\text { \$48.00 \$575.00 } \\
\text { Kids: } \\
\$ 18.00 \sim \$ 225.00\end{array}$ & $\begin{array}{l}\text { Over } 60 \\
\text { countries with } \\
\text { over } 700 \text { stores } \\
\text { and } 4.000 \\
\text { selected retailers }\end{array}$ \\
\hline
\end{tabular}

Asia

Japan owns an outstandingly large number of lifestyle shops in Asia compared to other countries. Among the various types of lifestyle brands, those whose business are large and shops are sufficient enough to advance into the world market are examined here. (Table 3.) In addition, MUJI and FRANC FRANC are brands that are popular in Korea as well; these brands have successfully managed their businesses for a long period of time with the differentiated and accurate concepts. Both Japan and China make each one's cultural characteristics well stand out. 
Table 3. Information of Lifestyle Brands in ASIA

\begin{tabular}{|c|c|c|c|c|c|}
\hline BRAND & COMPANY & CONCEPT & ITEM & PRICE & STORE \\
\hline MUJI & JAPAN & $\begin{array}{l}\text { Basic daily necessities } \\
\text { designed in the } \\
\text { desired forms }\end{array}$ & $\begin{array}{l}\text { clothing, shoes, } \\
\text { accessories, furniture, } \\
\text { fabric, kitchen, } \\
\text { cosmetic }\end{array}$ & $\begin{array}{l}\text { Fashion: } \\
¥ 2000 \sim ¥ 5000 \\
\text { Beauty: } \\
¥ 1000 \sim ¥ 4000 \\
\text { Household goods: } \\
¥ 300 \sim ¥ 15,000 \\
\text { Living: } \\
¥ 400 \sim ¥ 6000 \\
\text { Furniture: } \\
¥ 900 \sim ¥ 10,000\end{array}$ & $\begin{array}{l}372 \text { shops in Japan; } \\
\text { Overseas market: } 59 \\
\text { in Europe; } 200 \text { in } \\
\text { total }\end{array}$ \\
\hline $\begin{array}{l}\text { FRANC } \\
\text { FRANC }\end{array}$ & JAPAN & Stylish Casual & $\begin{array}{l}\text { clothing, shoes, } \\
\text { accessories, furniture, } \\
\text { kitchen, beauty, } \\
\text { interior }\end{array}$ & $\begin{array}{l}\text { Fashion: } \\
¥ 700 \sim ¥ 2500 \\
\text { Beauty: } \\
¥ 500 \sim ¥ 5000 \\
\text { Kitchen: } \\
¥ 400 \sim ¥ 3000 \\
\text { Furniture: } \\
¥ 4000 \sim ¥ 30,000 \\
\text { Interior: } \\
¥ 2000 \sim ¥ 15,000\end{array}$ & $\begin{array}{l}\text { Japan_116 } \\
\text { Overseas_13 shops }\end{array}$ \\
\hline $\begin{array}{l}\text { SHANGHA } \\
\text { I- TANG }\end{array}$ & HONG KONG & $\begin{array}{l}\text { Traditional patterns } \\
\text { and dress of China are } \\
\text { combined with } \\
\text { modern daily } \\
\text { necessities with the } \\
\text { unique and restorative } \\
\text { styles }\end{array}$ & $\begin{array}{l}\text { clothing, fashion } \\
\text { accessories, home }\end{array}$ & $\begin{array}{l}\text { Fashion: } \\
\text { \$101.00 } \$ 1.003 .00 \\
\text { Living: } \\
\$ 112.00 \sim \$ 573.00\end{array}$ & $\begin{array}{l}40 \text { local shops } \\
\text { around the world }\end{array}$ \\
\hline
\end{tabular}

\section{Korea, Republic of}

In fact, they were not lifestyle brands right from the beginning in Korea; all brands were total lifestyle commodities in expansion of such items as furniture, design, and household goods. (Table 4.) The table below shows the products that are the origin of each brand. According to the survey results, the items include Household Goods, Stationary Design, and Furniture.

Table 4. Information of Lifestyle Brands in KOREA, REPUBLIC OF

\begin{tabular}{|c|c|c|c|c|c|}
\hline BRAND & CATEGORY & CONCEPT & ITEM & PRICE & STORE \\
\hline $\begin{array}{l}\text { MODERN } \\
\text { HOUSE }\end{array}$ & Household Goods & European lifestyle & $\begin{array}{l}\text { furniture, bedding, } \\
\text { kitchen, window \& } \\
\text { carpet, decor, } \\
\text { tableware, storage }\end{array}$ & 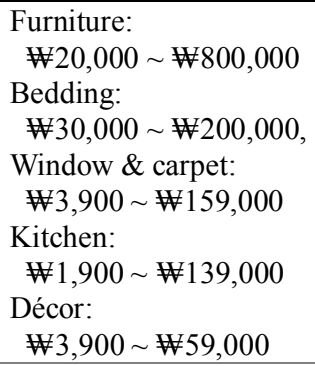 & $\begin{array}{l}36 \text { shops around the } \\
\text { country; } \\
\text { Seoul (10), } \\
\text { Gyeonggido (13), } \\
\text { Gyeongsangdo } \\
\text { (910), } \\
\text { Jeonrado (3) }\end{array}$ \\
\hline JAJU & & $\begin{array}{l}\text { "Nature-based" } \\
\text { natural urban life }\end{array}$ & $\begin{array}{l}\text { fashion, beauty \& } \\
\text { health, bath, kitchen } \\
\text { interior, home style }\end{array}$ & $\begin{array}{l}\text { Fashion: } \\
¥ 5,000 \sim \$ 35,000 \\
\text { Kitchen: } \\
¥ 1,500 \sim \$ 49,000 \\
\text { Bathroom: } \\
¥ 1,000 \sim \$ 33,900 \\
\text { Interior: } \\
¥ 1,900 \sim \$ 99,000 \\
\text { Beauty: } \\
¥ 3,000 \sim \$ 23,900\end{array}$ & $\begin{array}{l}\text { Flagship store of } \\
\text { JAJU in } \\
\text { Garosu-gil Road, } \\
\text { Shinsadong }\end{array}$ \\
\hline
\end{tabular}




\begin{tabular}{|c|c|c|c|c|c|}
\hline BRAND & CATEGORY & CONCEPT & ITEM & \begin{tabular}{|c|} 
PRICE \\
\end{tabular} & STORE \\
\hline $\begin{array}{c}\text { POOM, ART } \\
\text { BOX Inc. }\end{array}$ & Stationery Design & $\begin{array}{l}\text { All designs in the } \\
\text { world in one brand }\end{array}$ & $\begin{array}{l}\text { stationery design, } \\
\text { accessories, furniture, } \\
\text { fabric, home \& decor, } \\
\text { kitchen \& bath }\end{array}$ & 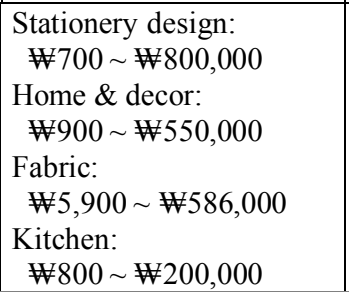 & $\begin{array}{l}\text { Simultaneous } \\
\text { running of online } \\
\text { and offline shops }\end{array}$ \\
\hline $10 \times 10$ & & $\begin{array}{l}\text { Making customerse } \\
\text { life special }\end{array}$ & $\begin{array}{l}\text { stationery design, } \\
\text { travel, toy, interior, } \\
\text { kitchen, fashion \& } \\
\text { beauty }\end{array}$ & 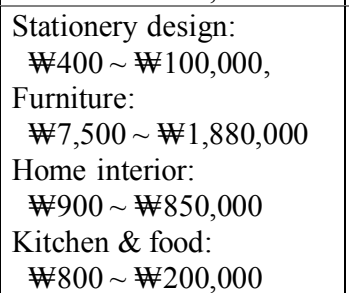 & 4 offline shops \\
\hline CASA-MIA & Furniture & $\begin{array}{l}\text { The most beautiful } \\
\text { house in the world; } \\
\text { pleasant home, a } \\
\text { house that is made } \\
\text { together with } \\
\text { customers }\end{array}$ & $\begin{array}{l}\text { bed room, living } \\
\text { room, dining \& décor, } \\
\text { home office, single } \\
\text { room, kids room, } \\
\text { home \& decor }\end{array}$ & 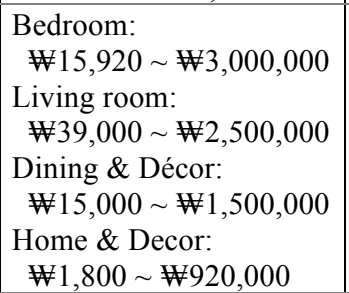 & $\begin{array}{l}21 \text { directly } \\
\text { managed shops } \\
\text { around the country; } \\
4 \text { shops in } \\
\text { department store } \\
\text { more than } 60 \\
\text { agencies }\end{array}$ \\
\hline HAN- SSEM & & $\begin{array}{l}\text { Contribution to } \\
\text { mankind's } \\
\text { advancement through } \\
\text { better housing } \\
\text { conditions }\end{array}$ & $\begin{array}{l}\text { bedroom, living } \\
\text { room, dining room, } \\
\text { home office, study } \\
\text { room, kids room, } \\
\text { household goods }\end{array}$ & 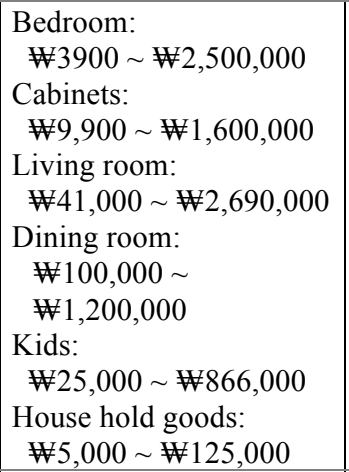 & $\begin{array}{l}25 \text { shops around } \\
\text { the country } \\
\text { (Hanssem } \\
\text { Flagshops) }\end{array}$ \\
\hline LIVART & & $\begin{array}{l}\text { Livart is your "life." } \\
\text { We live in Your Life, } \\
\text { Livart }\end{array}$ & $\begin{array}{l}\text { bedroom, living } \\
\text { room, kitchen, study } \\
\text { room, home style, } \\
\text { office }\end{array}$ & 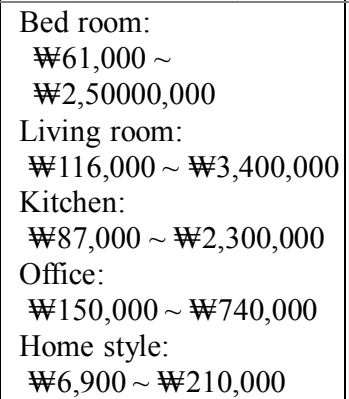 & $\begin{array}{l}14 \text { shops around } \\
\text { the country, Seoul } \\
\text { (4), Gyeonggi (5), } \\
\text { Gyeongsang (4), } \\
\text { Jeonra (1), (Livart } \\
\text { Style shops) }\end{array}$ \\
\hline
\end{tabular}

\section{GLOBAL LIFESTYLE BRAND}

In this study, among lifestyle brands that own shops around the world, whose brand awareness is high, and whose concept is accurate, those representing USA, EUROPE, and AISA, one from each country, were selected (Table 5). Particular attention was paid to Marketing Mix on such factors as Product, Price, Place, and Promotion. After the analysis of their current business strategies and SWOT, SWOT of global lifestyle brands were comprehensively examined (Figure 1). 
Table 5. 4P Marketing Mix of Global Lifestyle Brands

\begin{tabular}{|c|c|c|c|c|}
\hline BRAND & PRODUCT & PRICE & PLACE & PROMOTION \\
\hline $\begin{array}{l}\text { ANTHRO- } \\
\text { POLOGIE }\end{array}$ & $\begin{array}{l}\text { - Emphasis on quality } \\
\text { that corresponds to the } \\
\text { high prices } \\
\text { - Collaboration with } \\
\text { designers for variety of } \\
\text { items } \\
\text { - For competition with } \\
\text { other companies, the } \\
\text { business was recently } \\
\text { expanded to male and } \\
\text { child items }\end{array}$ & $\begin{array}{l}\text { - In the } 4^{\text {th }} \text { quarter of } \\
2014, \text { competitive } \\
\text { items and shop } \\
\text { shopping experiences } \\
\text { are provided for sales } \\
\text { increase }\end{array}$ & $\begin{array}{l}\text { - Unique displays in } \\
\text { each of the } 82 \text { shops } \\
\text { over the U.S. (regional } \\
\text { features, climates, and } \\
\text { customer preferences } \\
\text { considered) } \\
\text { - } 2 \text { stationed visual } \\
\text { merchandisers } \\
\text { - Set designers create } \\
\text { new sets of designs for } \\
\text { each store in every } \\
\text { season }\end{array}$ & $\begin{array}{l}\text { - Instead of } \\
\text { advertisement through } \\
\text { mass media, the } \\
\text { expenses are invested } \\
\text { into creative space } \\
\text { presentation } \\
\text { - Online(SNS) marketing } \\
\text { to establish a network } \\
\text { - anthro loyalty program } \\
\text { for a variety of services }\end{array}$ \\
\hline $\begin{array}{l}\text { MARKS \& } \\
\text { SPENCER }\end{array}$ & $\begin{array}{l}\text { Products are known for } \\
\text { their first-class quality, } \\
\text { reliability, style, and } \\
\text { variety. } \\
\text { - among the top quality } \\
\text { garments } \\
\text { manufacturers in the } \\
\text { world }\end{array}$ & $\begin{array}{l}\text { reasonable price to } \\
\text { very expensive price } \\
\text { most of its products } \\
\text { have premium prices } \\
\text { which only target a } \\
\text { specific upper class of } \\
\text { consumers }\end{array}$ & $\begin{array}{l}\text { Easily available in the } \\
\text { cities and towns of UK } \\
\text { as well as other } \\
\text { developed countries. } \\
\text { - Sells its garment } \\
\text { products on internet } \\
\text { through online } \\
\text { shopping portals, like } \\
\text { Amazon.com and its } \\
\text { own website. }\end{array}$ & $\begin{array}{l}\text { Done through all the } \\
\text { marketing mediums; } \\
\text { like advertisements on } \\
\text { television, internet and } \\
\text { social media, major } \\
\text { newspapers, fashion } \\
\text { magazines, Marks and } \\
\text { Spencer's broachers, } \\
\text { etc. }\end{array}$ \\
\hline MUJI & $\begin{array}{l}\text { - Focus on sustainable } \\
\text { item production } \\
\text { - Careful selection of } \\
\text { high quality, and } \\
\text { sustainable materials; } \\
\text { use of completely } \\
\text { disposable materials } \\
\text { - No-brand strategy and } \\
\text { "simple design" to } \\
\text { focus on the essential } \\
\text { and intrinsic value of } \\
\text { products }\end{array}$ & $\begin{array}{l}\text { - Simple design with no } \\
\text { superfluous elements; } \\
\text { cost-saving by } \\
\text { reducing unnecessary } \\
\text { production lines } \\
\text { - Despite the slogan of } \\
\text { MUJI, advancement } \\
\text { into overseas markets } \\
\text { inevitably involves } \\
\text { increase of } \\
\text { transportation costs and } \\
\text { tariffs, which limits the } \\
\text { price competitiveness }\end{array}$ & $\begin{array}{l}\text { - Since } 1991 \text { when the } \\
\text { first overseas shop was } \\
\text { opened in London, } 59 \\
\text { are run in Europe; } \\
\text { more than } 200 \text { overseas } \\
\text { shops in total } \\
\text { - Advancement into } \\
\text { Middle East Asia and } \\
\text { Islamic regions as well } \\
\text { as Europe being } \\
\text { accelerated }\end{array}$ & $\begin{array}{l}\text { - More opportunities for } \\
\text { the shop manager to } \\
\text { listen directly to } \\
\text { customers and to } \\
\text { reflect their opinions } \\
\text { - Money-making system } \\
\text { planning rather than } \\
\text { removing useless } \\
\text { elements } \\
\text { (commonness, } \\
\text { grouping, automation) } \\
\text { - Inventory sell-off, } \\
\text { removal of low-sales } \\
\text { shops to reduce loss. }\end{array}$ \\
\hline
\end{tabular}


Figure 1. SWOT Analysis of 3 Global Lifestyle Brands

\begin{tabular}{|c|c|c|}
\hline & $\begin{array}{l}\text { - Reasonable Price } \\
\text { - Simplistic \& minimalist } \\
\text { - Design } \\
\text { - No direct competition } \\
\text { - Locations } \\
\text { - Customer loyalty } \\
\text { - Unique product } \\
\text { - Innovation }\end{array}$ & $\begin{array}{l}\text { - Limited target market } \\
\text { - High level of price } \\
\text { - Easily substitutable } \\
\text { product design } \\
\text { - Don't use a lot of } \\
\text { advertising and } \\
\text { promotional tools }\end{array}$ \\
\hline & S & $N$ \\
\hline $\begin{array}{l}\text { - Expansion of online } \\
\text { methods and categories } \\
\text { - Growth Globalization } \\
\text { - Ethical foods } \\
\text { - Customer segmentation } \\
\text { - Sustainable consumption } \\
\text { - Collaboration }\end{array}$ & $\begin{array}{l}\text { - Clear concepts } \\
\text { - Range expandable } \\
\text { - Brands with little } \\
\text { competitors } \\
\text { - Customer integrity } \\
\text { - Collaboration with other } \\
\text { business types } \\
\text { - A variety of services }\end{array}$ & $\begin{array}{l}\text { - More thorough customer } \\
\text { categorization } \\
\text { - Attempts of various } \\
\text { marketing strategies } \\
\text { - Assurance of quality that } \\
\text { corresponds to the high } \\
\text { prices }\end{array}$ \\
\hline $\begin{array}{l}\text { - Less competitive in terms } \\
\text { of } \\
\text { - Price } \\
\text { - Variation and rapid change } \\
\text { of customer needs } \\
\text { - External changes } \\
\text { - (government, politics, } \\
\text { taxes) } \\
\text { - Product substitution } \\
\text { - Economy Slowdown }\end{array}$ & $\begin{array}{l}\text { Difficulty in producing } \\
\text { alternative items due to } \\
\text { the clear concept; } \\
\text { - Disadvantageous in terms } \\
\text { of comprehensive } \\
\text { industry occupation due } \\
\text { to mass production }\end{array}$ & $\begin{array}{l}\text { - Unable to meet changing } \\
\text { needs of customers } \\
\text { - Limited targets; high } \\
\text { prices } \\
\text { - Difficulty in prompt } \\
\text { supply of alternative } \\
\text { items due to } \\
\text { - the limited distribution }\end{array}$ \\
\hline
\end{tabular}

The analysis results indicate that global lifestyle brands attract consumers with clear concepts or themes and readily expand the range of products. On the other hand, the concepts are so clear that it is difficult to develop alternative items and meet the rapidly changing needs of consumers. Since they are lifestyle brands, however, there are limitless potentials to extend various promotion strategies in collaboration with various other life-related business areas. In addition, since such brands are based on distribution businesses, it may be sometimes difficult to keep the supply prompt and provide necessary support swiftly. Hence, developing product groups that represent a brand also can be a strategy. 


\section{TREND ANALYSIS FOR KOREAN LIFESTYLE BRAND}

\section{Korean Lifestyle Trend}

In order to predict the development direction of Korean lifestyle brands, it is necessary to investigate lifestyle trends among Koreans. In that sense, related trends were classified macroscopically into SOCIETY, ECONOMY, and TECHNOLOGY, and the major keywords extracted regarding Koreans' current interests were analyzed.

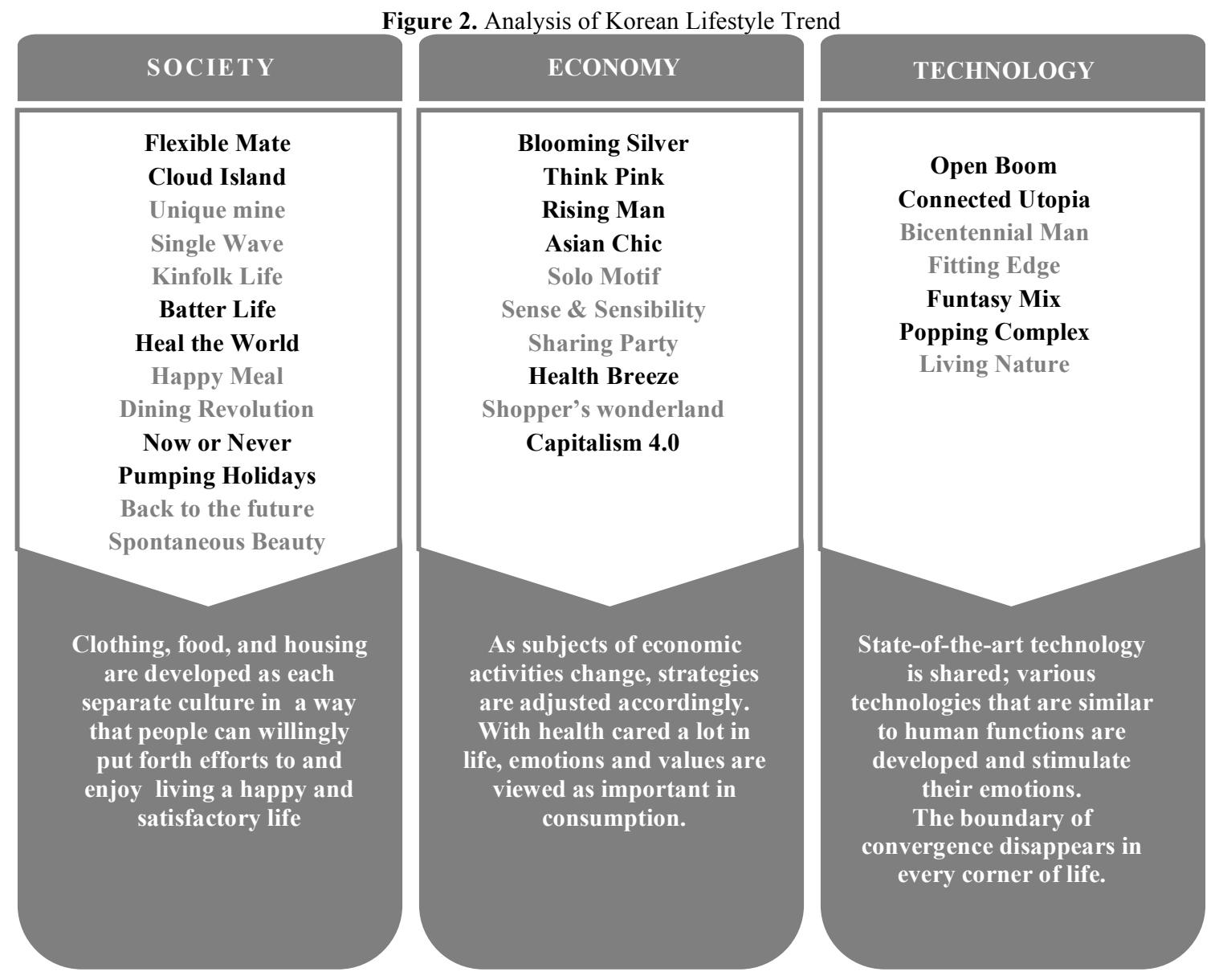

\section{Society Trend}

As individuals' life is viewed as important, people are freer and care about now more than the future. They endeavor to live a meaningful life and find joys even from trivial and humble things. To enjoy such happy moments, people willingly pursue a younger and more energetic life even if it requires more investment.

\section{Economy Trend}

As to economic activities in Korea, the female-centered consumption is changing with increasing attention to men and isolated classes such as the elderly and sexual minorities. Rather than the distinction of sex, personal and individual preferences in consumption will be regarded as more important, and items for them will be developed accordingly. As the number of those living alone is increasing, how to guar one's own health is drawing keen attention. People want their consumption to be practical and valuable for themselves. The Korean waves and Eastern cultures make Asian cultures globally known. 


\section{Technology Trend}

Today, new technologies and even patents are shared. Cloud functions make it possible to link everything, and technologies are customized to individuals' styles and personalities. Robots started representing human features to the point that they understand and reproduce human emotions. People long for nature. The boundary of convergence in culture and life is broken down and its potential is limitless.

\section{KOREAN LIFESTYLE BRAND TREND}

This section prospects the future trends of Korean lifestyle brands. First of all, to examine the business directions, prospects, and current investment areas of companies, industry trends are analyzed; customer trends are also investigated to fathom recognition of lifestyle brands among domestic consumers and their evaluations of brands.

Figure 3. Analysis of Korean Lifestyle Brand Trend
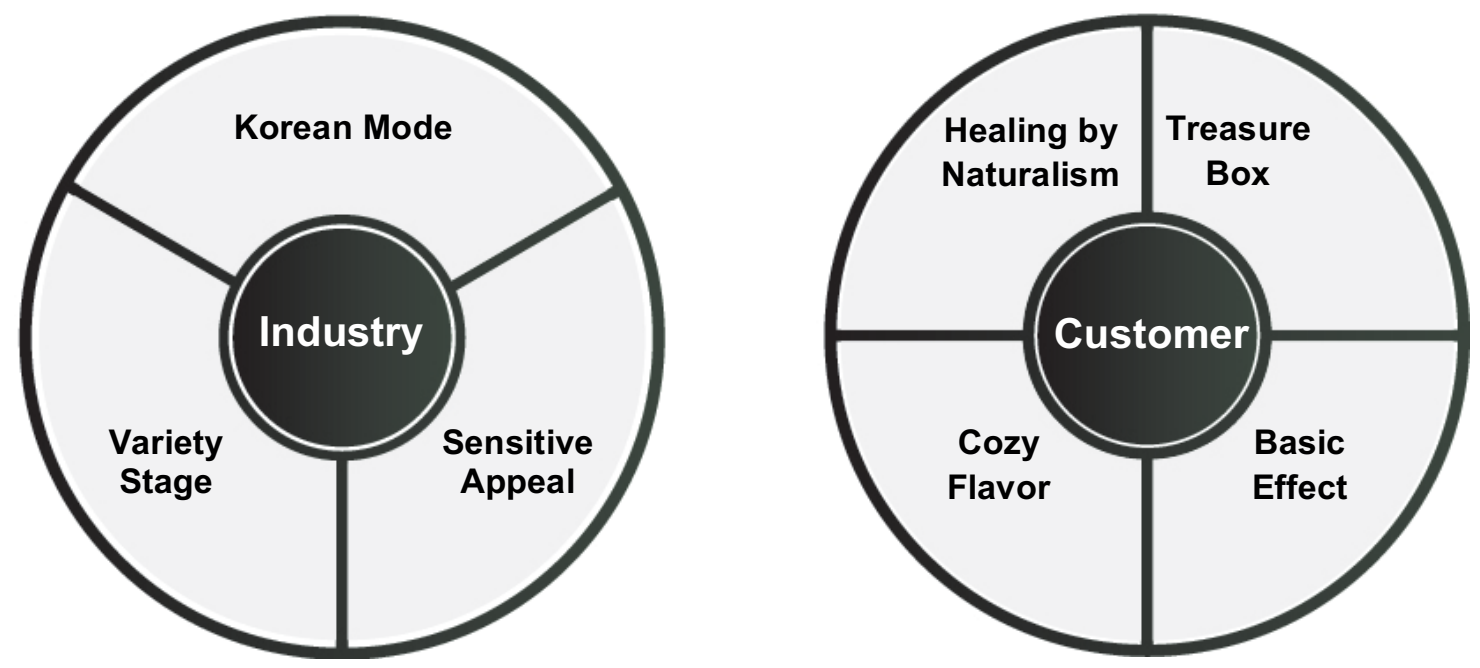

\section{Industry Trend}

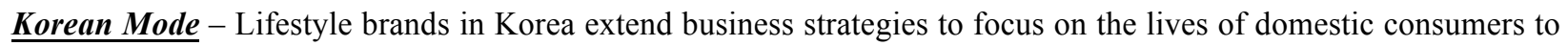
design lifestyle shops aiming at the domestic market. They create Korean items differentiated from those of global lifestyle brands and investigate concepts and products that Koreans would desire.

Variety Stage - As complex shopping spaces are becoming common in Korea, product categories cooperative customer services are expanding accordingly. In particular, since lifestyle brands should value presentation of concepts ideal, not only to specific items, but to the whole life of the consumers, various and unique customer services are attempted.

Sensitive Appeal - As contact points with customers are more specified and needs of consumers who care a lot about uniqueness are more and more increasing, brands are trying to stimulate consumers' emotions by inducing them with shops with stories and concepts and attracting promotion methods as well as enhancing product competitiveness through value differentiation.

\section{Customer Trend}

Cozy Flavor - Consumers who care much about uniqueness desire simple designs that reflect one's own preferences and tastes. Brands should secure comfort and stability and the products should not be different from one's lifestyle even if they are not splendid but simple. 
$\underline{\text { Treasure Box }}$ - Interesting display elements, space for special experiences, and unique flavors in the lifestyle shops make customers feel that pleasant imagination comes true with the "treasure box."

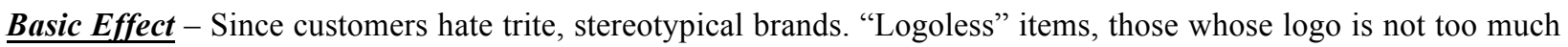
outstanding, are drawing attention. People are looking at general styles, rather than brands themselves. They desire practical items in harmony with their own lives and little affected by vogue. Consumers desire designs that are goodlooking, easy to wear, and quality.

Healing by Naturalism - As consumers who pursue a healing life prefer items made of natural materials, not harmful to nature, and long-lasting, eco-friendly products are drawing attention.

\section{DEVELOPMENT DIRECTION OF KOREAN LIFESTYLE BRAND}

Based on the thorough analysis of the trends in Korea and lifestyle brands, home and abroad, this study suggests the future development directions of Korean lifestyle brands as follows:

First, brands should embrace and reflect Korean emotions of domestic consumers and global lifestyles at the same time. Since the Internet technology of Korea is highly advanced, people readily access updated information and thus have keen senses about global fashions. To introduce lifestyle brands with Korean emotions to such domestic consumers, understanding of Korean traditions and cultures, rather than mere Korean motifs, is essential in creating concepts. For instance, the philosophies of Hara Kenya and MUJI brands resemble typical Japanese; they are modern but reflect Japanese cultures and national characters. While Korea has Eastern cultures similar to those of Japan, it has its own classical features and vintage that have developed against the historical background.

Second, themes and concepts should be unique in terms of space and image. Current lifestyle trends pursue unique elements that can make my personalities stand out rather than splendid features. Hence, global lifestyle brands as well suggest unique lifestyle concepts with related items in harmony with one another. Korean lifestyle brands are advantageous in that they understand what domestic consumers desire, and thus they should suggest concepts that consumers would seek realistically.

Third, the number of single households is increasing in Korea, and they are in different age groups. Thus, suggesting lifestyle concepts of small items for single or small family users also can be a strategy of differentiation. Not only small sizes but also practical functions and usages for the elderly and single households should be taken into consideration.

Fourth, recent lifestyle brand trends among companies and consumers indicate that the boundary between different business types are broken down and original cooperation is realized. Consumers pursue humble and comfort feelings and prefer natural materials and products. However, there is no Korean lifestyle brand that presents a memorable, outstanding concept in this regard. The brand name, "JAJU," which is a shorter term of "naturalism" in Korean, does not seem quite appealing. Cooperation with regional industry sectors that are prosperous is necessary, therefore, to represent themes with each brand's color well reflected and each lifestyle standing out. As a result, the images of brands will be enhanced, and special products of regions that are reliable and more sophisticated will be available in lifestyle shops.

\section{CONCLUSION}

As global lifestyle brands that have advanced into Korean markets are catching a lot of popularity, domestic lifestyle-related businesses are expanding the product categories and renewing themselves as Korean lifestyle brands. Related domestic brands, however, are experts of certain items and have limitations in representing general lifestyles. In contrast, worldly renowned global lifestyle brands are attracting consumers with precise concepts.

Accordingly, this study analyzes Korean lifestyles accurately and suggests the development directions of Korean lifestyle brands. Domestic companies have attempted to appeal consumers with Korean elements, active cooperation, and emotions while consumers sought practical, comfortable, and natural items that secure the 
fundamental values. Thus, Korean lifestyle brands need to present lifestyle concepts that embrace different generations and are readily approachable and emotional.

It is hoped that in the future, the study on Korean lifestyle brands touch on design-centered emotional concepts and expanded product development in line with regional situations in Korea. In addition, since many of the domestic brands were originated from certain items in certain business sectors, design strategies need to take into consideration general lifestyles. To become global lifestyle brands, it is also essential to come up with concepts that clearly represent Korean emotions.

\section{ACKNOWLEDGEMENT}

This work was supported NRF (National Research Foundation of Korea) Grant funded by the Korean Government (NRF-2015-Fostering Global Convergence Design Frontier for the Future Leadership in 'New Growth Engine Project').

\section{AUTHOR BIOGRAPHIES}

Ken Nah, corresponding author, is the dean of International Design school for Advanced Studies (IDAS), Hongik University, Republic of Korea and a professor of design management. He has a CPE (the certified professional ergonomists) in U.S.A. He studies for design thinking and ergonomics with design. He is the president of Korea Institute of Design Management in Korea.

Soojin Oh, lead author, is a Ph.D. of design theory at IDAS, Hongik University in Korea, republic of. She studied fashion design as a M.A. and B.A. also. She is a lecturer of universities and company about fashion marketing, fashion graphic design, and fashion portfolio. For convergent design thinking and concept marketing for lifestyle brand or products, these are her main study fields.

Keunhee Kwon, co-author, belongs to NRF (National Research Foundation of Korea) Grant funded by the Korean Government (NRF-2015-Fostering Global Convergence Design Frontier for the Future Leadership in 'New Growth Engine Project'). She has studied about Design Management under the supervision Prof. Ken Nah at International Design school for Advanced Studies, Hongik University, Republic of Korea. She worked on Universal Design Research Center. She earned a bachelor's degree from Kyungsung University in 2014.

Youjin Han, co-author, has studied about Design Management at International Design school for Advanced Studies(IDAS), Hongik University, Republic of Korea. she was exchange student in collaborative and Industrial Design department at Aalto university in Finland (2015). Youjin received her B.A. in Industrial Design from Gachon University (2014). She has participated in various art works, including "The Biennale di Venezia 14th International Exhibitions of Architecture" (2014).

\section{REFERENCES}

Ahn, S.H. (2012,10,01). Now life! Comes New version select shop. Fashionbiz. Retrieved from http://www.fashionbiz.co.kr/FL/main.asp?cate=2\&idx=128877.

Anthropologie SWOT Analysis. (n.d.). Retrieved from http://www.wikiswot.com/SWOT/4_/Anthropologie.html

Arndt, Michael. (2010). Urban Outfitters' Grow-Slow Strategy. BusinessWeek, 4168, 56-57.

Cho, T.J. (2013,03,11). 'Japaness life' What is the secret charm of MUJI? Fashionbiz. Retrieved from $\mathrm{http}: / /$ www.fashionbiz.co.kr $/ \mathrm{WW} /$ main.asp?cate $=2 \& \mathrm{idx}=131789 \&$ pageNo $=1 \&$ sty $=\mathrm{T} \& \mathrm{ste}=\% \mathrm{~B} 9 \% \mathrm{AB} \% \mathrm{C} 1 \% \mathrm{~F} 6$

Cho, T.J. $(2014,04,21)$. Attention! Life style shop creator. Fashionbiz. Retrieved from http://www.fashionbiz.co.kr/WW/main.asp?cate=2\&idx=139440

Company Overview. (2011). Anthropologie, Inc. Hoover's Online. Retrieved from http://subscriber.hoovers.com.libdata.lib.ua.edu/H/company360/overview.html?companyId=789001179

Darden, W.R. (1980). A patronage model of consumer behavior. Competitive. American Marketing Association.

Dudovskly, J. (2012). Marks \& Spencer (M\&S) SWOT Analysis. research-methodology.net. Retrieved from http://researchmethodology.net/marks-spencer-ms-swot-analysis/

Eom, K.H.\&Pyo, J.Y. (2014). A Case Study on Lifestyle Shop in Fashion. Korea Digital Design Coucil. $253(2), 505$. 
Hwang, J.H., Kim, M.,\&Koo, J.J. (2014). An impact of Life-style shop`s Internal-external Factors casuing Sensory Experience on Customers' Intention to Revisit. Korean Society of Basic Design \& Art. 473(12),1598-8635.

Jung, J.G. (2014,06,27). ECO has become Fashion Trend. MK NEWS. Retrieved from http://news.mk.co.kr/newsRead.php?no=933358\&year=2014

Kang, I.H. (2013). The Relationship between Single' Leisure Attitude\& Recognition of Dances Life Style and Department of Dance. The Graduate School Sejong University. 20(8).

K-ECO EXPO. (2014,03,17), New Consumption Patterns Thinking of Environment. Sustainable Consumption and Production (SCP).2014 K-ECO EXPO

Ken Nah, Cathy Lee. (2010). Trend Power Station. Culture Code. South Korea

Kim, D.H. (2014,04,03), That is the what smart women buy new arrivals, Open Survey

Kim, H.T. (2014). trendkeyword.pdf, Market cast.

Kim, J.H. (2014). A Relationship Between Lifestyle of University Students and Factors of Restaurant Choice, The Korea Academic Society of Tourism and Leisure. 143(20),1229-0424.

Kim, Y. J. (2014,04,07). M\&S, For the next three years will be opened 250 stores overseas. Egreennews. Retrieved from Ko, H.Z. (2013). The Design Aesthetics of the Finnish Brand Marimekko. The Korean Society of Fashion Design. 111-128.

Koh, E.B., \&Choi, K.R. (2009). A Study on a VMD of Lifestyle Shop applying Experiential Marketing - VMD case studies on IKEA, MUJI, and Kosney. Korean Society of Basic Design \& Art. 29(9),1598-8635.

Lee, A.H. (2013,03,06). Life style shop, from 「JAJU」 to $\lceil\mathrm{POOM}$ purple ocean! Fashionbiz, Retrieved from http://www.fashionbiz.co.kr/BR/main.asp?cate=2\&sub_num=104\&pageNo=1\&idx $=131722$

Lee, A.H. $(2014,05,12)$. [TOKYO], The golden age of Life style, Fashionbiz. Retrieved from http://www.fashionbiz.co.kr/WW/main.asp?cate=2\&idx=140005

Lee, A.H. $(2014,06,24)$. Life style shop comes in the second half. Fashionbiz. Retrieved from http://www.fashionbiz.co.kr/TN/main.asp?cate=2\&idx=140688

Lee, E.A. (2014). The Effect of Consumption Values on Selection Criteria and Purchase Intention of Lifestyle Shoppers. The Graduate School Konkuk University. 4(16).

Martin, T. (2012). Muji: A Role Model of the Sustainable Marketing Mix. Sustainable Business. Retrieved from http://www.susbus.com/muji-a-role-model-of-the-sustainable-marketing-mix/

MUJI Analysis. (2011). Retrieved from https://www.google.co.kr/url?sa=t\&rct=j\&q=\&esrc=s\&source=web\&cd=1\&ved=0CCkQFjAA\&url=http $\% 3 \mathrm{~A} \% 2 \mathrm{~F} \% 2 \mathrm{~F}$ d284f45nftegze.cloudfront.net\%2Ffumikamigama\%2FMUJI_MEDIAKIT.pdf\&ei=2g7VU53WMIq78gWg2oLgCg\&us g=AFQjCNHjK8LCYeRXuYC4a2a9AiDhxesaJw\&sig2=hfVwnofQrI2MAYajL0a4OA\&bvm=bv.71778758,d.dGc\&ca $\mathrm{d}=\mathrm{rjt}$

Oakley,W. (2013). Marks and Spencer's Current 4 P's of Marketing - The Marketing Mix. Retrieved from http://professionalpaper-writing-service.blogspot.kr/2013/05/marks-and-spencers-current-4-ps-of.html

Olshavsky, Richard W., Donald H. Granbois. (1979). Consumer Decision Making: Fact or Fiction? Journal of Consumer Research.

Park, H.G. (2014). Understand the customer's lifestyle! Korea marketing Institute. 40-48.

Park, J.H. (2014,07,13). LG economic research institute '7 types lifestyle of korean consumers', efnews. Retrieved from http://www.efnews.co.kr/sub_read.html?uid=17572\&section=sc22

People List (2011). Anthropologie, Inc. Hoover's Online. Retrieved from http://subscriber. hoovers.com.libdata.lib.ua.edu/H/company360/people.html? companyId=789001179

Pink, D. H. (2007). A Whole New Mind. Putnam Pub Group. Come to new future.The Korea Economic Daily.

Rodrigo, (2012). Strategic Analysis of Marks and Spencers Plc (M\&S).The write pass journal. Retrieved from http://writepass.com/journal/2012/12/ms-and-modifies-its-business-strategies/

Seok, H.J. (2006,09,01). Charming Anthropologie. Fashionbiz. Retrieved from http://www.fashionbiz.co.kr/FL/main.asp?cate=2\&idx=833\&uidx=1259

The Anthropologist (2011). Retrieved from http://theanthropologist.net/

ULF Pillkahn. (2009). Trends and Scenarios. Leadersbook. South Korea

Urban Outfitters Reports Reord $4^{\text {th }}$ Quarter Operating Profit (2010). Glove Newswire. Retrieved from http://www.globenewswire. 


\section{NOTES}

